\title{
Modulation of Alzheimer-Like Synaptic and Cholinergic Deficits in Transgenic Mice by Human Apolipoprotein E Depends on Isoform, Aging, and Overexpression of Amyloid $\beta$ Peptides But Not on Plaque Formation
}

\author{
Manuel Buttini, ${ }^{1}$ Gui-Qiu Yu, ${ }^{1}$ Kristina Shockley, ${ }^{1}$ Yadong Huang, ${ }^{1}$ Brian Jones, ${ }^{1}$ Eliezer Masliah, ${ }^{3}$ \\ Margaret Mallory, ${ }^{3}$ Tracy Yeo, ${ }^{2,4}$ Frank M. Longo, ${ }^{2,4}$ and Lennart Mucke ${ }^{1,2}$ \\ ${ }^{1}$ Gladstone Institute of Neurological Disease, and ${ }^{2}$ Department of Neurology, University of California, San Francisco, \\ California 94141-9100, ${ }^{3}$ Departments of Neurosciences and Pathology, University of California at San Diego, La Jolla, \\ California 92093-0624, and ${ }^{4}$ Veterans Affair’s Medical Center, San Francisco, California 94121
}

\begin{abstract}
The most frequent human apolipoprotein (apo) $E$ isoforms, E3 and $E 4$, differentially affect Alzheimer's disease (AD) risk (E4 > E3) and age of onset (E4 < E3). Compared with apoE3, apoE4 promotes the cerebral deposition of amyloid $\beta(A \beta)$ peptides, which are derived from the amyloid precursor protein (APP) and play a central role in $A D$. However, it is uncertain whether $A \beta$ deposition into plaques is the main mechanism by which apoE isoforms affect $A D$. We analyzed murine apoE-deficient transgenic mice expressing in their brains human APP (hAPP) and A $\beta$ together with apoE3 or apoE4. Because cognitive decline in $A D$ correlates better with decreases in synaptophysin-immunoreactive presynaptic terminals, choline acetyltransferase (ChAT) activity, and ChAT-positive fibers than with plaque load, we compared these parameters in hAPP/apoE3 and hAPP/apoE4 mice and singly transgenic controls at 6-7, 12-15, and 19-24 months of age. Brain aging in the context of high levels of nondeposited
\end{abstract}

human $A \beta$ resulted in progressive synaptic/cholinergic deficits. ApoE3 delayed the synaptic deficits until old age, whereas apoE4 was not protective at any of the ages analyzed. Old hAPP/apoE4 mice had more plaques than old hAPP/apoE3 mice, but synaptic/ cholinergic deficits preceded plaque formation in hAPP/apoE4 mice. Moreover, despite their different plaque loads, old hAPP/ apoE4 and hAPP/apoE3 mice had comparable synaptic/ cholinergic deficits, and these deficits were found not only in the hippocampus but also in the neocortex, which in most mice contained no plaques. Thus, apoE3, but not apoE4, delays ageand $A \beta$-dependent synaptic deficits through a plaque-independent mechanism. This difference could contribute to the differential effects of apoE isoforms on the risk and onset of AD.

Key words: acetylcholine; aging; Alzheimer's disease; amyloid; apolipoprotein E; cholinergic; neurodegeneration; synapses; transgenic
Alzheimer's disease (AD) is an age-dependent neurodegenerative disorder that is characterized by a progressive cognitive decline and by characteristic morphological CNS alterations, including deposition of amyloid $\beta$ peptides $(\mathrm{A} \beta)$ in parenchymal plaques and cerebral blood vessels; intraneuronal formation of neurofibrillary tangles; and loss of neuronal subpopulations, synaptophysin-immunoreactive (SYN-IR) presynaptic terminals, and cholinergic fibers (Terry et al., 1999). Different gene products have been implicated in the pathogenesis of this disease. Earlyonset autosomal dominant forms of familial AD (FAD) have been linked to mutations in genes encoding amyloid precursor protein (APP), presenilin 1, and presenilin 2 (Selkoe, 2001). Mutations in these genes alter the processing of APP such that increased amounts of either total $\mathrm{A} \beta$ or $\mathrm{A} \beta$ ending at residue 42 (A $\beta 42)$ are produced (Selkoe, 2001).

Although mutations in APP or presenilin genes account for

\footnotetext{
Received April 17, 2002; revised Aug. 29, 2002; accepted Sept. 4, 2002.

This work was supported by National Institutes of Health Grants AG11385 and NS41787 and by a Zenith Award (99-1847) from the Alzheimer's Association. We thank D. Selkoe for the 1282 antibody, J. Carroll and S. Gonzales for preparation of graphics, G. Howard and S. Ordway for editorial assistance, and D. McPherson for administrative assistance.

Correspondence should be addressed to Dr. Lennart Mucke, P.O. Box 419100, San Francisco, CA 94141. E-mail: lmucke@gladstone.ucsf.edu.

Copyright (C) 2002 Society for Neuroscience 0270-6474/02/2210539-10\$15.00/0
}

only a fraction of AD cases, inheritance of the apolipoprotein (apo) $\mathrm{E} \in 4$ allele is the major known genetic risk factor for the most common type of AD (Farrer et al., 1997). ApoE is a $34 \mathrm{kDa}$ lipid carrier protein that participates in the maintenance and repair of neurons (Mahley and Huang, 1999). It is expressed at high levels in the brain and can be produced by diverse cell types, including neurons, astrocytes, and microglia (Boyles et al., 1985; Stone et al., 1997; Buttini et al., 1999; Xu et al., 1999, 2000; Dekroon and Armati, 2001). In humans, apoE occurs in three major isoforms, which are associated with different risks of developing AD (E4 > E3 > E2) (Corder et al., 1993; Farrer et al., 1997). The two most frequent isoforms differ not only in their effects on $\mathrm{A} \beta$ deposition (E4 > E3) (Rebeck et al., 1993; Schmechel et al., 1993; Berr et al., 1994; Heinonen et al., 1995; Hyman et al., 1995; Gearing et al., 1996; Ishii et al., 1997; Johnson et al., 1998; McNamara et al., 1998; Holtzman et al., 2000a,b) but also in their capacity to protect the brain against diverse injuries, including those elicited by excitotoxins, ischemia, and trauma (E3 > E4) (Sheng et al., 1998; Buttini et al., 1999, 2000; Horsburgh et al., 2000; Sabo et al., 2000). Although any or all of these effects might play a role in $\mathrm{AD}$, some studies have suggested that the main effect of apoE isoforms is through plaque formation (Holtzman et al., 2000a,b), whereas others have provided evidence for plaque-independent mechanisms (Raber et al., 2000). 
Differentiating whether AD-related neuronal deficits are caused by plaques, $\mathrm{A} \beta$ fibrils, or nonfibrillar $\mathrm{A} \beta$ species is an important conundrum in AD research (Klein et al., 2001). Human $A \beta$ is neurotoxic when added to cultures of neural cells or tissue sections (Pike et al., 1993; Yankner, 1996; Klein et al., 2001), injected into the brain (Geula et al., 1998), or produced in neurons of transgenic mice (Games et al., 1995; Masliah et al., 1996, 2001; Nalbantoglu et al., 1997; Calhoun et al., 1998; Price et al., 1998; Hsia et al., 1999; Mucke et al., 2000). However, both in vitro and in vivo, $\mathrm{A} \beta$ can exist in diverse conformational states. Which of these states is responsible for the dysfunction and degeneration of neurons in AD remains a matter of active study and debate (Terry, 1996; Davis and Chisholm, 1997; Hartley et al., 1999; Hsia et al., 1999; Lue et al., 1999; McLean et al., 1999; Mucke et al., 2000; Näslund et al., 2000; Klein et al., 2001). Both deposited and nondeposited forms of $\mathrm{A} \beta$ might contribute to the pathogenesis of $\mathrm{AD}$, but their relative contributions have been difficult to dissect, both in humans and in experimental models. Although neuritic dystrophy appears to be closely linked to plaques (Knowles et al., 1999), evidence is mounting that ADrelated synaptic degeneration and functional neuronal impairments may be caused primarily by nondeposited forms of $\mathrm{A} \beta$ (Lambert et al., 1998; Hartley et al., 1999; Holcomb et al., 1999; Hsia et al., 1999; Lue et al., 1999; McLean et al., 1999; Mucke et al., 2000; Raber et al., 2000; Klein et al., 2001).

To investigate the effects of apoE isoforms on AD-related deficits in vivo and, in particular, the possible relationship between the development of such deficits and the amyloidogenic effect of apoE4, we analyzed transgenic mice expressing human APP (hAPP)/A $\beta$ in combination with either apoE3 or apoE4 in the brain. We focused our analysis on SYN-IR presynaptic terminals, choline acetyltransferase (ChAT) activity, and cholinergic fibers, because decreases in these parameters correlate well with cognitive decline in AD (Terry et al., 1991; Samuel et al., 1997; Sze et al., 1997; Brown et al., 1998). ChAT synthesizes the neurotransmitter acetylcholine (ACh) and is produced by cholinergic neurons clustered in a number of cell groups in the basal forebrain (Cummings, 2000). Its activity is 40-90\% lower in AD brains than in control brains, and this reduction correlates with cognitive decline (Perry et al., 1978; Davies, 1979; Wilcock et al., 1982; Sims et al., 1983; Neary et al., 1986; Bierer et al., 1995; Samuel et al., 1997; Cummings, 2000).

In mice, lack of murine apoE or expression of human $A \beta$ in the presence of murine apoE is also associated with age-dependent synaptic and cholinergic deficits (Games et al., 1995; Gordon et al., 1995; Masliah et al., 1995a,b, 1996, 2001; Buttini et al., 1999, 2000; Hsia et al., 1999; Mucke et al., 2000). However, these models did not allow an analysis of potential interactions between human $\mathrm{A} \beta$ and human apoE. In the current study, we analyzed hAPP/apoE3 and hAPP/apoE4 mice that express human $\mathrm{A} \beta$ in the context of human apoE and therefore more closely simulate the situation encountered in the human brain.

Previous studies of hAPP/apoE transgenic mice focused primarily on amyloid deposition and plaque-related pathology (Holtzman et al., 1999, 2000a,b) but did not examine effects of human apoE isoforms on other AD-related deficits, such as loss of SYN-IR presynaptic terminals, ChAT activity, or cholinergic fibers. The results we obtained in the current study suggest that apoE3 but not apoE4 can delay some age- and A $\beta$-dependent neuronal deficits through a plaque-independent neuroprotective mechanism.
Table 1. Relative levels of SYN-IR presynaptic terminals in transgenic mice

\begin{tabular}{|c|c|c|c|}
\hline \multirow[b]{2}{*}{ Genotype $^{a}$} & \multicolumn{3}{|l|}{ Age } \\
\hline & 6-7 months & $12-15$ months & 19-24 months \\
\hline \multicolumn{4}{|l|}{ Neocortex } \\
\hline apoE3 & +++ & +++ & +++ \\
\hline apoE4 & ++ & + & + \\
\hline hAPP/apoE3 & +++ & $++(+)$ & + \\
\hline hAPP/apoE4 & ++ & + & + \\
\hline hAPP & + & + & + \\
\hline$A p o e^{-/-}$ & + & + & + \\
\hline \multicolumn{4}{|l|}{ Hippocampus } \\
\hline apoE3 & +++ & +++ & +++ \\
\hline apoE4 & +++ & + & + \\
\hline hAPP/apoE3 & +++ & +++ & + \\
\hline hAPP/apoE4 & +++ & + & + \\
\hline hAPP & +++ & + & + \\
\hline Apoe $e^{-1-}$ & +++ & + & + \\
\hline
\end{tabular}

$\overline{{ }^{a} \text { All mice }(n=4-7 \text { per genotype and age group) lacked murine apoE. }+++ \text {, Levels }}$ comparable with those found in nontransgenic wild-type mice (Buttini et al., 1999); ++ , moderate reduction; + , most prominent reduction. For quantitative data, see Figure 2 and Results. For illustrations, see Figure 4.

\section{MATERIALS AND METHODS}

Animals. The generation of murine apoE-deficient transgenic mice expressing FAD-mutant hAPP, directed by the platelet-derived growth factor (PDGF) B chain promoter (line J9), in combination with either apoE3 or apoE4, directed by the neuron-specific enolase (NSE) promoter, has been described previously (Raber et al., 1998, 2000; Buttini et al., 1999; Hsia et al., 1999; Mucke et al., 2000). For the current study, we used a total of 102 mice, bred to be $>95 \%$ C57BL/6J. Six genotypes and three age groups were analyzed (Table 1). Each genotype and age group contained approximately the same number of males and females. No significant differences were identified between age- and genotypematched male and female mice with respect to any of the endpoints analyzed. Mice were anesthetized with chloral hydrate and flushperfused transcardially with $0.9 \%$ saline. Brains were removed and divided sagitally. One hemibrain was postfixed in phosphate-buffered $4 \%$ paraformaldehyde, $\mathrm{pH} 7.4$, at $4^{\circ} \mathrm{C}$ for $48 \mathrm{hr}$ for vibratome sectioning. The neocortex, hippocampus, and medial septum were dissected from the other hemibrain on ice, frozen immediately on dry ice, and stored at $-70^{\circ} \mathrm{C}$ until analysis.

$A \beta$ measurements. Frozen brain tissues were homogenized in guanidine buffer, and human $\mathrm{A} \beta$ peptides were quantitated by ELISA as described previously (Johnson-Wood et al., 1997). The A $\beta 1-42$ ELISA detects only $A \beta 1-42$, whereas the $A \beta 1$-x ELISA detects $A \beta 1-40, A \beta 1-$ $42, A \beta 1-43$, and $C$-terminally truncated forms of $A \beta$ containing amino acids $1-28$.

Immunohistochemistry for $\mathrm{A} \beta$ was performed on $50 \mu \mathrm{m}$ free-floating vibratome sections of paraformaldehyde-fixed brain tissue. Endogenous peroxidase activity was quenched by incubating sections in $3 \% \mathrm{H}_{2} \mathrm{O}_{2}$ in PBS with $0.5 \%$ Triton $\mathrm{X}-100$ for 20 min. To block nonspecific binding sites, sections were incubated for $1 \mathrm{hr}$ at room temperature in $15 \%$ goat serum (Vector Laboratories, Burlingame, CA). Sections were then incubated overnight at $4^{\circ} \mathrm{C}$ with a 1:6000 dilution of R1282 antibody (gift from D. Selkoe, Brigham and Women's Hospital, Boston, MA). Sections were then washed twice in PBS and incubated for $1 \mathrm{hr}$ with a 1:200 dilution of biotin-labeled anti-rabbit as a secondary antibody (Vector Laboratories). Secondary antibody binding was detected with the ABC Elite kit (Vector Laboratories) using diaminobenzidine and $\mathrm{H}_{2} \mathrm{O}_{2}$ as chromagenic substrates. A $\beta$-immunoreactive deposits were visualized by bright-field microscopy with a $4 \times$ objective and photographed with an Axiocam digital camera (Zeiss, Weimar, Germany).

Although the $\mathrm{A} \beta$ antibody detects both diffuse and fibrillar amyloid deposits, thioflavin-S (thio-S) detects primarily fibrillar amyloid and, hence, is widely used to detect more mature amyloid plaques (Schmidt et al., 1995). Thio-S-positive amyloid plaques were visualized in $50 \mu \mathrm{m}$ vibratome sections with a staining protocol adapted from Schmidt et al. 
(1995). Briefly, sections were mounted onto SuperFrost glass slides (Fisher Scientific, Houston, TX) and air-dried. After fixation for $10 \mathrm{~min}$ in $3.7 \%$ formalin, they were rinsed twice in PBS and immersed in $0.25 \%$ $\mathrm{KMnO}_{4}$ in PBS for $10 \mathrm{~min}$. After another rise in PBS, they were immersed for $5 \mathrm{~min}$ in a solution containing $2 \% \mathrm{~K}_{2} \mathrm{O}_{5} \mathrm{~S}_{2}$ and $1 \%$ oxalic acid. After a $10 \mathrm{~min}$ rinse in water, sections were incubated for $10 \mathrm{~min}$ in a $0.015 \%$ thio-S solution in $50 \%$ ethanol, differentiated in $50 \%$ ethanol, washed in water, air-dried, and coverslipped. Sections were examined by confocal microscopy (MRC 1024 or Radiance 2000; Bio-Rad, Hercules, CA) with an FITC filter set. Digitized images were transferred to a computer, and the average percentage area of the hippocampus occupied by thio-S-positive plaques in three to four sections per mouse (plaque load) was determined with NIH Image.

ApoE measurements. ApoE levels in brain tissues were quantitated by Western blot analysis as described previously (Huang et al., 1996, 2001). Briefly, brain tissues were homogenized in $0.3 \mathrm{ml}$ of ice-cold lysis buffer containing $50 \mathrm{~mm}$ Tris/ $\mathrm{HCl}, \mathrm{pH} 8.0,150 \mathrm{~mm} \mathrm{NaCl}, 4 \%$ SDS, $1 \%$ Nonidet P-40, $1 \%$ sodium deoxycholate, and protease inhibitors. After determination of protein concentrations by the Lowry method, samples $(100 \mu \mathrm{g}$ total proteins per lane) were subjected to SDS-PAGE and analyzed by Western blotting with an anti-human apoE antibody. Sample bands were compared with standards containing different amounts of recombinant human apoE3 or apoE4 by densitometric analysis.

ApoE immunohistochemistry was performed on $50 \mu \mathrm{m}$ vibratome sections. Endogenous peroxidase was quenched by incubation in $3 \%$ $\mathrm{H}_{2} \mathrm{O}_{2} / 10 \%$ methanol in PBS for 15 min, and nonspecific binding sites were blocked with a mixture of $10 \%$ rabbit serum, $1 \%$ nonfat dry milk, $0.2 \%$ gelatin, and $0.2 \%$ Triton X-100. Anti-apoE (Calbiochem, San Diego, CA) was diluted 1:28,000, and biotin-labeled anti-goat secondary antibody was diluted 1:200. Secondary antibody binding was detected with the ABC Elite kit (Vector Laboratories) using diaminobenzidine and $\mathrm{H}_{2} \mathrm{O}_{2}$ as chromagenic substrates. The specificity of this immunostain has been documented previously (Buttini et al., 1999). Photomicrographs were taken with an AxioCam digital camera (Zeiss) coupled to an Olympus Optical (Tokyo, Japan) BX-60 microscope.

$S Y N-I R$ presynaptic terminals. Vibratome sections ( $n=2$ per mouse) labeled first with an anti-synaptophysin monoclonal antibody (diluted 1:40; Boehringer Mannheim, Mannheim, Germany) and then with an FITC-coupled anti-mouse antibody (diluted 1:75; Vector Laboratories) were imaged, essentially as described previously (Buttini et al., 1999), with a Radiance 2000 laser scanning confocal microscope mounted on an Olympus BX-60 microscope using a $60 \times$ oil objective. Sections were assigned code numbers to ensure objective assessment, and codes were not broken until the analysis was complete. The density of SYN-IR presynaptic terminals was assessed in the strata radiatum and lacunosum of the hippocampus (CA1 subfield) and in layers $2-5$ of the frontoparietal neocortex. For each mouse, we analyzed three to four optical sections of the stratum radiatum and the stratum lacunosum and four to six optical sections of the neocortex.

Staining of sections with antibody dilutions that are either too high or too low can obscure differences between experimental and control groups, yielding false negative results. To avoid this problem, we injected wild-type mice with saline or kainate as described previously (Buttini et al., 1999) and performed pilot experiments to determine the dilutions of primary and secondary antibodies at which differences in the intensity of synaptophysin immunostaining between these groups were maximal. The optimized antibody dilutions were then used for the current study as described above. To further ensure the reliability of our quantitations, for each experiment, we first determined the linear range of fluorescence intensity and density of SYN-IR presynaptic terminals in sections from wild-type mice (data not shown). This setting of the confocal microscope was then used to collect all images analyzed in the same experiment. The density of SYN-IR presynaptic terminals was expressed as percentage of the image area occupied by immunoreactive structures of defined signal intensity. Digitized images were transferred to a computer (Apple Computers, Cupertino, CA) and analyzed with the public domain program NIH Image. As reviewed recently (Buttini et al., 1999), the above approach has been used successfully in various experimental models of neurodegeneration and diseased human brain and has been validated by comparisons with quantitative immunoblots, ELISAs, and the optical disector probe.

ChAT activity and immunoreactivity. ChAT activity in the medial septum of 3-10 mice per genotype was determined by previously described procedures (Yeo et al., 1997). Medial septum tissue was sonicated in $50 \mathrm{~mm}$ Tris/0.2\% Triton X-100 buffer, $\mathrm{pH} 7.4$ (diluted 1:20, wet w/v), and centrifuged at maximum speed in an Eppendorf centrifuge. The supernatant was transferred to another tube, and soluble protein levels were determined by bicinchoninic acid assay (Pierce, Rockford, IL). Samples from each mouse were diluted $1: 5$ with $50 \mathrm{~mm}$ Tris $/ 0.5 \mathrm{M}$ sodium-phosphate buffer, $\mathrm{pH} 7.0$, to a final volume of $50 \mu \mathrm{l}$, mixed with $50 \mu \mathrm{l}$ of reaction buffer $(0.4 \mathrm{M} \mathrm{NaCl}, 80 \mu \mathrm{g} / \mathrm{ml}$ eserine, $12 \mathrm{~mm}$ choline chloride, $10 \mu \mathrm{g} / \mathrm{ml}$ albumin, and $0.05 \mu \mathrm{Ci}{ }^{14} \mathrm{C}$-labeled acetyl $\mathrm{CoA}$ in Na-phosphate buffer), and incubated at $37^{\circ} \mathrm{C}$ for $30 \mathrm{~min}$. Background readings for each mouse were obtained by boiling duplicate tissue samples for $5 \mathrm{~min}$ before mixing them with the reaction buffer. Reactions were stopped with $500 \mu \mathrm{l}$ of ice-cold $\mathrm{H}_{2} \mathrm{O}$ and loaded onto a column with 1 inch of Dowex 1X-A beads (Bio-Rad). Columns were washed twice with $600 \mu \mathrm{l}$ of $\mathrm{H}_{2} \mathrm{O}$, and all of the column effluents were collected and counted on a Beckman (Fullerton, CA) scintillation counter. The amount of ACh synthesized was calculated and expressed as nanomoles per milligram of protein per hour.

Immunohistochemistry for ChAT was performed on $50 \mu \mathrm{m}$ freefloating vibratome sections of paraformaldehyde-fixed brain tissue. Endogenous peroxidase activity was quenched by incubating sections in $3 \%$ $\mathrm{H}_{2} \mathrm{O}_{2}$ in PBS with $0.5 \%$ Triton X-100 for 20 min. To block nonspecific antibody binding, sections were incubated for $15 \mathrm{~min}$ in Superblock (Scytek, Logan, UT). Sections were then incubated overnight at $4^{\circ} \mathrm{C}$ with anti-ChAT antibody (diluted 1:3500; Chemicon, Temecula, CA). Sections were then washed twice in PBS and incubated for $1 \mathrm{hr}$ with biotin-labeled anti-goat secondary antibody (diluted 1:200; Vector Laboratories). Secondary antibody binding was detected with the ABC Elite kit using diaminobenzidine and $\mathrm{H}_{2} \mathrm{O}_{2}$ as chromagenic substrates. For all sections, the development reaction was stopped after 2 min by transferring the sections into $0.1 \mathrm{M}$ Tris, $\mathrm{pH}$ 7.5. After two washes in the same buffer, sections were mounted, air-dried, and coverslipped. Digitized images of the immunostained sections were obtained with a DEI-450 Optronics digital camera (Coleta, CA) mounted on a BX-60 microscope (Olympus Optical) using a $20 \times$ magnification lens, and the integrated optical density of the immunoperoxidase product over defined areas was quantitated with the BioQuant Image Analysis package (R\& M Biometrics, Nashville, TN). For each mouse, three to four measurements per brain region were obtained and averaged. Four to seven animals were analyzed per group. Dilutions of primary and secondary antibodies and development times for the chromagenic reaction were optimized in pilot experiments to maximize the reliability of the immunostain (see also above). To further standardize our measurements, control sections from the same three wild-type mice (two sections per mouse) were included in each staining experiment, and all sections were processed and measured under similar conditions. Measurements in experimental mice were expressed as the percentage of integrated optical density readings obtained in corresponding regions of the wild-type control sections.

Statistical analyses. Statistical analyses were performed with the StatView 5.0 program (SAS Institute, Cary, NC). Differences among means were assessed by Mann-Whitney $U$ test or by one-way ANOVA followed by Tukey-Kramer post hoc test as appropriate.

\section{RESULTS \\ Generation of hAPP/apoE doubly transgenic mice
lacking murine apoE}

To study the influence of human apoE isoforms on AD-related neuropathological alterations, we bred murine apoE-deficient PDGF-hAPP transgenic mice from line J9 (Hsia et al., 1999; Mucke et al., 2000; Raber et al., 2000) (hAPP mice) with murine apoE-deficient NSE-apoE mice (apoE mice) that express apoE3 or apoE4 in the brain at levels similar to those in human cortex (Buttini et al., 1999). These crosses yielded six groups of mice, all of which lacked murine apoE $\left(\right.$ Apoe $\left.^{-/-}\right)$: doubly transgenic mice (hAPP/apoE3 or hAPP/apoE4), singly transgenic mice (hAPP, apoE3, or apoE4), and mice lacking human transgenes. ApoE3 and apoE4 singly transgenic mice show similar levels and distributions of human apoE in the brain (Raber et al., 1998; Buttini et al., 1999), and 6-month-old hAPP/apoE3 and hAPP/apoE4 mice have comparable levels of $\mathrm{A} \beta 1-42$ and $\mathrm{A} \beta 1-\mathrm{x}$ (approximates total $A \beta$ ) in the hippocampus (Raber et al., 2000). In the current study, we made similar observations (data not shown) and ex- 


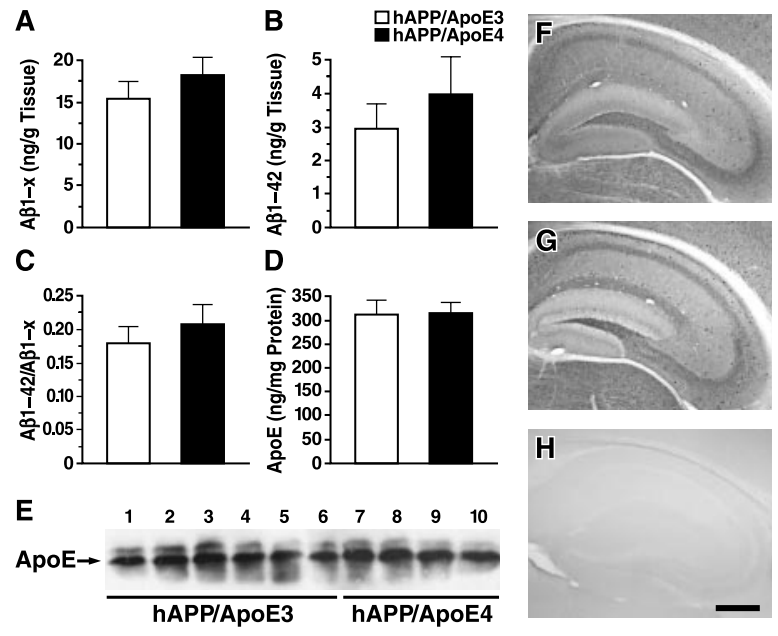

Figure 1. Comparable levels of human $\mathrm{A} \beta$ and apoE in brain tissues of hAPP/apoE3 and hAPP/apoE4 mice. $A-E$, Snap-frozen neocortex from 12- to 15-month-old hAPP/apoE3 mice and hAPP/apoE4 mice $(n=4-7$ per genotype) was homogenized and analyzed for human $\mathrm{A} \beta 1-\mathrm{x}$ or A $\beta 1-42$ by ELISA and for human apoE by quantitative Western blot analysis. hAPP/apoE3 (open bars) and hAPP/apoE4 ( filled bars) mice had comparable $\mathrm{A} \beta 1-\mathrm{x}$ levels $(A), \mathrm{A} \beta 1-42$ levels $(B), \mathrm{A} \beta 1-42 / \mathrm{A} \beta 1-\mathrm{x}$ ratios $(C)$, and apoE levels $(D)$. Values in $A-D$ represent group means \pm SEM. $E$ depicts a representative Western blot demonstrating similar apoE levels in hAPP/apoE3 mice (lanes 1-6) and hAPP/apoE4 mice (lanes 7-10). $F-H$, The distribution of human apoE in the hippocampus of 12- to 15 -month-old mice was determined by anti-apoE immunoperoxidase staining of paraformaldehyde-fixed vibratome sections in a hAPP/apoE3 mouse $(F)$ and a hAPP/apoE4 mouse $(G)$. An Apoe $^{-1-}$ mouse served as a control $(H)$. Scale bar, $400 \mu \mathrm{m}$ (applies to $F-H$ ).

tended these findings to another brain region and an older age group (Fig. 1).

\section{ApoE3 but not apoE4 delays the age-dependent decline in SYN-IR presynaptic terminals in hAPP mice expressing high levels of soluble human $\mathbf{A} \boldsymbol{\beta}$}

On the murine apoE wild-type background, hAPP mice develop an age-dependent loss of SYN-IR presynaptic terminals that is associated with major deficits in synaptic transmission strength (Hsia et al., 1999; Mucke et al., 2000). To detect potential apoE isoform-specific effects on age-related synaptic impairments in the context of human $\mathrm{A} \beta$ production, we determined the levels of SYN-IR presynaptic terminals in the neocortex (layers 2-5, frontoparietal region) and hippocampus (strata radiatum and lacunosum) by computer-assisted confocal image analysis. Six genotypes were analyzed at three age ranges (Table 1).

On the murine apoE-deficient background, hAPP mice also developed an age-related decline in SYN-IR presynaptic terminals in all three brain regions analyzed (Fig. 2). ApoE3 significantly delayed this decline, whereas apoE4 did not (Table 1, Figs. $2,4)$. At 6-7 (neocortex) and 12-15 (neocortex and hippocampus) months of age, hAPP/apoE3 mice had higher levels of SYN-IR presynaptic terminals than hAPP/apoE4 mice, hAPP mice, or Apoe ${ }^{-/-}$mice lacking human transgenes (Table 1, Figs. 2, 4). The levels of SYN-IR presynaptic terminals in hAPP/apoE3 mice at these ages were normal (i.e., similar to those of age-matched wild-type controls without human transgenes) (Masliah et al., 1995b; Buttini et al., 1999, 2000; Hsia et al., 1999; Mucke et al., 2000) (data not shown). The levels of SYN-IR presynaptic terminals in hAPP/apoE4 mice were abnormally low and comparable to those in age-matched hAPP mice with or without murine
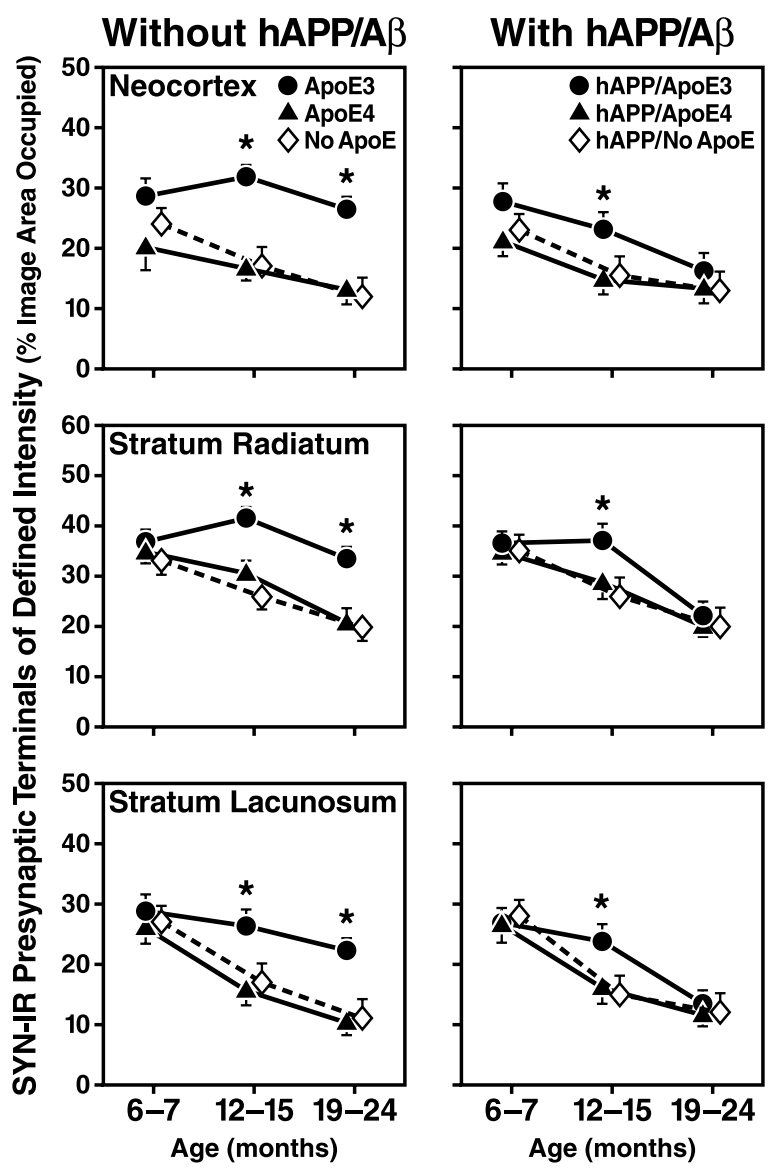

Figure 2. Age-related changes in presynaptic terminals of apoE singly transgenic (left) and hAPP/apoE doubly transgenic (right) mice lacking murine apoE. Littermates expressing neither human nor murine apoE served as additional controls. The density of SYN-IR presynaptic terminals in the strata radiatum and lacunosum of the hippocampus and in the neocortex was determined by confocal microscopy and computer-assisted image analysis. ApoE4 mice and hAPP/apoE4 mice showed a significant loss of SYN-IR presynaptic terminals at $12-15$ and 19-24 months in all three brain regions. Like nontransgenic, wild-type $\left(\right.$ Apoe $\left.^{+/+}\right)$mice (Buttini et al., 1999, 2000) (data not shown), apoE3 mice had no significant age-dependent loss of SYN-IR presynaptic terminals. In hAPP/ apoE3 mice, the loss of SYN-IR presynaptic terminals was delayed until 19-24 months of age, when it was comparable to that in age-matched hAPP/apoE4 mice. ApoE-deficient mice with or without hAPP/A $\beta$ expression developed an age-related loss of SYN-IR presynaptic terminals similar to that of apoE4 or hAPP/apoE4 mice. Results represent means \pm SEM; $n=4-7$ mice per genotype and age range; $* p<0.05$, age-matched mice expressing apoE3 versus apoE4 (Tukey-Kramer test).

apoE expression and to those in $A p o e^{-1-}$ mice lacking human transgenes (Fig. 2) (Masliah et al., 1995b; Buttini et al., 1999, 2000; Hsia et al., 1999; Mucke et al., 2000).

Although apoE3 was able to protect hAPP/apoE3 mice against synaptic deficits at 6-7 and 12-15 months of age, it failed to do so at 19-24 months of age (Table 1, Figs. 2, 4). By 19-24 months of age, levels of SYN-IR presynaptic terminals had declined to similar levels in hAPP/apoE3 and hAPP/apoE4 mice (Figs. 2, 4). In the absence of $\mathrm{hAPP} / \mathrm{A} \beta$, apoE3 was able to protect even the oldest murine apoE-deficient mice against synaptic deficits (Fig. 2). In contrast, apoE4 failed to protect against synaptic deficits at all ages tested, compared with apoE-deficient controls with or without hAPP/A $\beta$ expression (Table 1, Fig. 2). 


\section{ApoE3 protects murine apoE-deficient mice against age-dependent cholinergic deficits but only if they do not produce human $\mathbf{A} \boldsymbol{\beta}$}

To investigate the effect of apoE isoforms on ChAT in the presence or absence of human $\mathrm{A} \beta$, we analyzed ChAT activity in the medial septum, which contains cell bodies of ACh-producing neurons, and ChAT-IR fibers in the neocortex and hippocampus, which contain cholinergic terminals. Murine apoE-deficient mice developed an age-dependent loss of ChAT activity and ChAT-IR fibers that was prevented by apoE3 but not by apoE4 (Fig. 3). However, this protective effect of apoE3 was not seen in mice expressing high levels of human $\mathrm{A} \beta$, consistent with results obtained in hAPP mice expressing wild-type murine apoE (Boncristiano, 2002). Both hAPP/apoE4 and hAPP/apoE3 mice showed a comparable age-dependent loss of ChAT activity and ChAT-IR fibers (Figs. 3, 4).

\section{The effects of apoE3 and apoE4 on synaptic deficits in hAPP/apoE mice are not attributable to their differential effects on plaque formation}

To assess the age-dependent formation of amyloid plaques, we stained brain sections of murine apoE-deficient hAPP/apoE3 mice, hAPP/apoE4 mice, and hAPP mice with thio-S. No thio-Spositive plaques were detected at 6-7 and 12-15 months of age in any of these mice (Figs. 4, 5). By 19-24 months of age, numerous plaques were found in the hippocampus of hAPP/apoE4 mice (Figs. 4, 5), whereas only few plaques were detected in the hippocampus of age-matched hAPP/apoE3 mice (Figs. 4, 5) or hAPP mice lacking apoE (data not shown). Plaques were most numerous in the stratum lacunosum in hAPP/apoE4 mice and almost completely restricted to this region in hAPP/apoE3 mice (Fig. 4). Thio-S-positive plaques were detected in the neocortex in one of seven hAPP/apoE4 mice and none of eight hAPP/apoE3 mice (data not shown).

To detect amyloid deposits that might be too diffuse to stain with thio-S, we stained brain sections of hAPP/apoE3 and hAPP/ apoE4 mice with a polyclonal anti-A $\beta$ antibody (R1282). Like thio-S-positive plaques, A $\beta$-IR deposits were detected only at 19-24 months of age but not at 6-7 or 12-15 months of age (Fig. 4). A $\beta$-IR deposits were detected primarily in the strata radiatum, oriens, and lacunosum of the hippocampus and were more numerous and dense in hAPP/apoE4 mice than in hAPP/apoE3 mice (Fig. 4). Only two of seven hAPP/apoE4 and none of eight hAPP/apoE3 had A $\beta$-IR deposits in the neocortex (data not shown).

Notably, at 12-15 months of age, hAPP/apoE4 mice already had a significant loss of SYN-IR presynaptic terminals and ChAT-IR fibers in the stratum lacunosum, although they had not yet formed plaques or diffuse amyloid deposits (Figs. 2-5). In 19to 24-month-old hAPP/apoE4 mice, plaque load did not correlate with levels of SYN-IR presynaptic terminals or ChAT-IR fibers (Spearman's rank correlation). Furthermore, hAPP/apoE3 and hAPP/apoE4 mice showed marked differences in plaque load in the stratum lacunosum at 19-24 months of age but very similar losses of SYN-IR presynaptic terminals and ChAT-IR fibers (Table 1, Figs. 2-5). hAPP/apoE3 and hAPP/apoE4 mice showed an age-dependent decline in SYN-IR presynaptic terminals and ChAT-IR fibers in the neocortex (Figs. 2, 3), although A $\beta$-IR deposits were detected in this region in only two hAPP/apoE4 mice and thio-S-positive plaques were detected in only one hAPP/
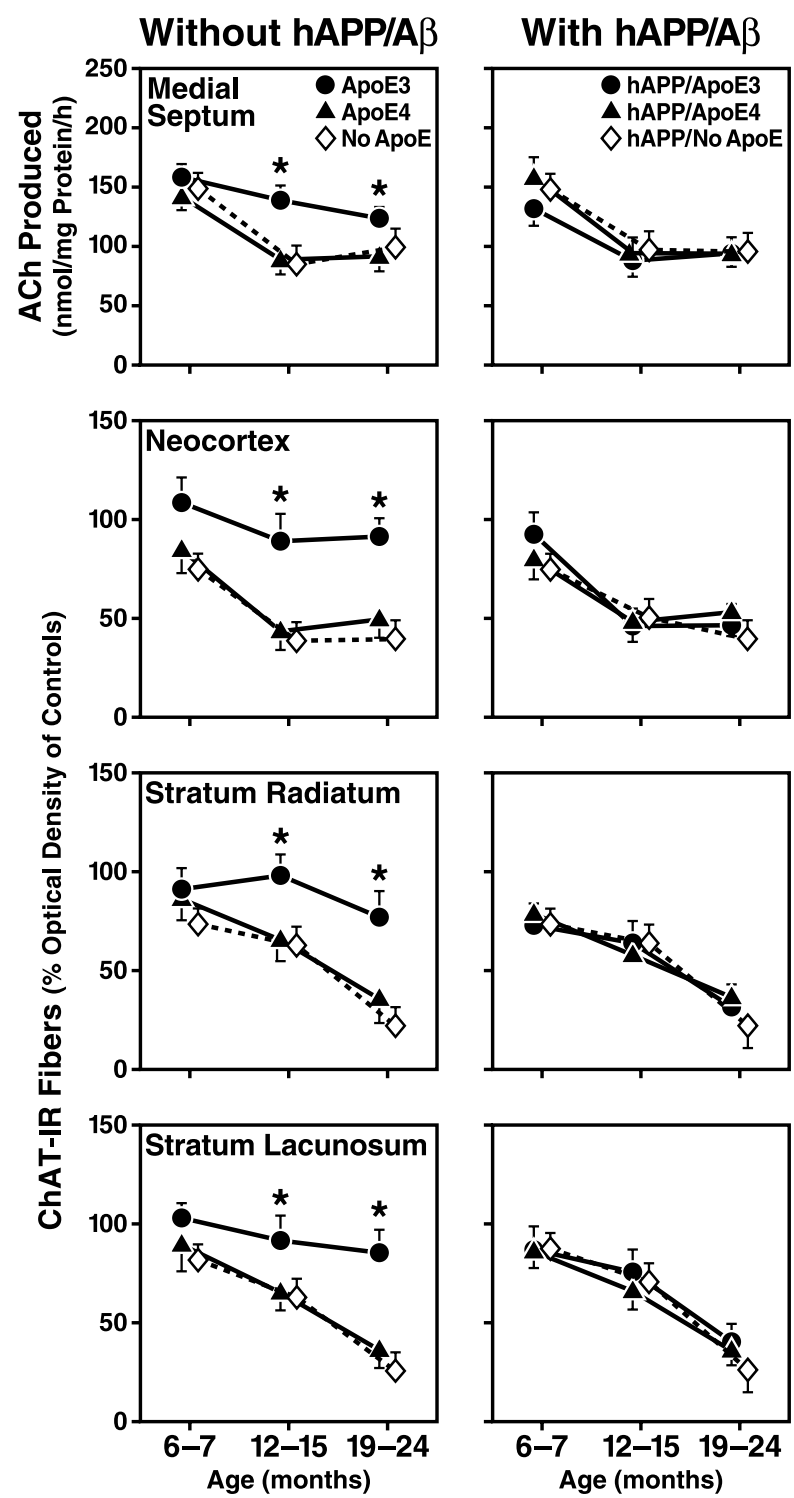

Figure 3. Age-related changes in ChAT activity (top row) and ChAT-IR fibers (bottom rows) in apoE singly transgenic (left) and hAPP/apoE doubly transgenic (right) mice lacking murine apoE. Littermates expressing neither human nor murine apoE served as additional controls. ChAT activity was measured in the medial septum. Levels of ChAT-IR fibers in the strata radiatum and lacunosum of the hippocampus and in the neocortex were expressed as percentage of corresponding levels in nontransgenic, wild-type $\left(\mathrm{Apoe}^{+/+}\right)$control mice. Compared with apoE3 mice, apoE4 mice showed a loss of ChAT activity and ChAT-IR fibers at 12-15 and 19-24 months of age but not at 6-7 months of age. hAPP/apoE mice showed an age-related loss of ChAT regardless of whether they expressed apoE3 or apoE4. Age-related losses of ChAT in apoE-deficient mice with or without hAPP expression were similar to those in apoE4 mice. Results represent means $\pm \mathrm{SEM} ; n=3-10$ (ChAT activity) and $n=4-7$ (ChAT-IR fibers) mice per genotype and age range; ${ }^{*} p<0.05$, agematched mice expressing apoE3 versus apoE4 (Tukey-Kramer test). ChAT activity measurements for one 19-month-old apoE3 mouse and one 12-month-old apoE4 mouse were excluded from the statistical analysis because they were well outside of the range of the other values.

apoE4 mouse (data not shown). Lastly, no $\mathrm{A} \beta$-IR deposits or plaques were found in the medial septum and nucleus basalis magnocellularis (data not shown), which give rise to the ChAT-IR fibers of the neocortex and hippocampus, respectively. 


\section{hAPP/ApoE3}

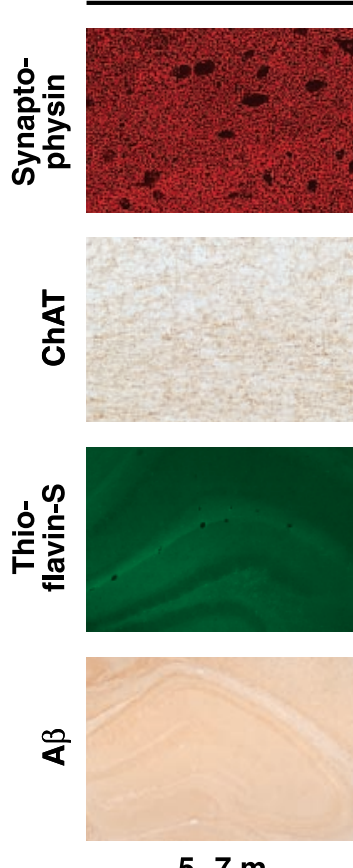

5-7 m
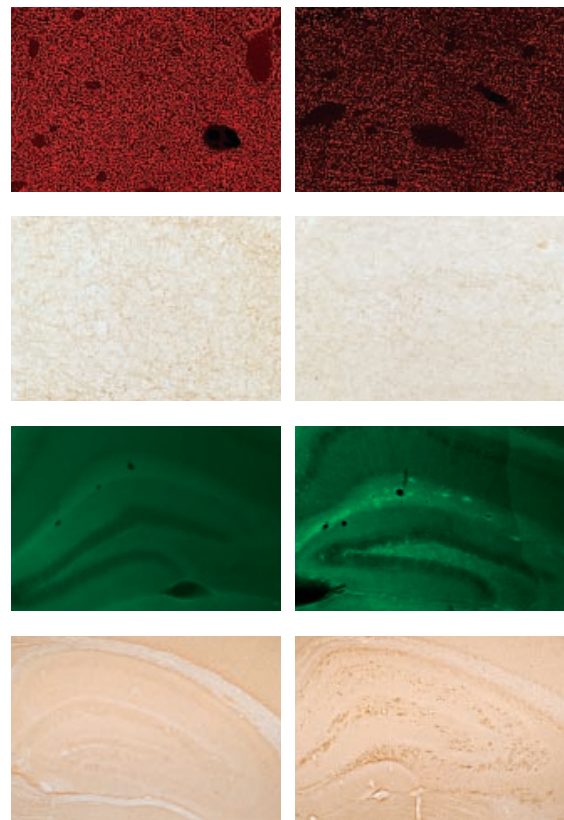

12-15 m
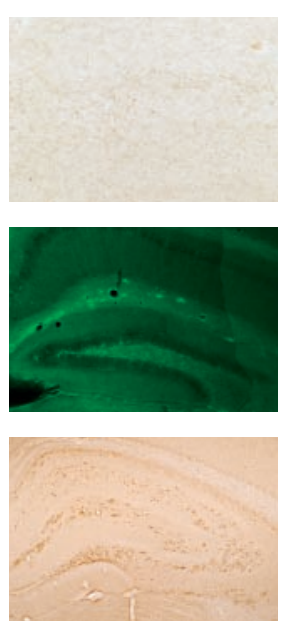

19-24 m
hAPPIApoE4
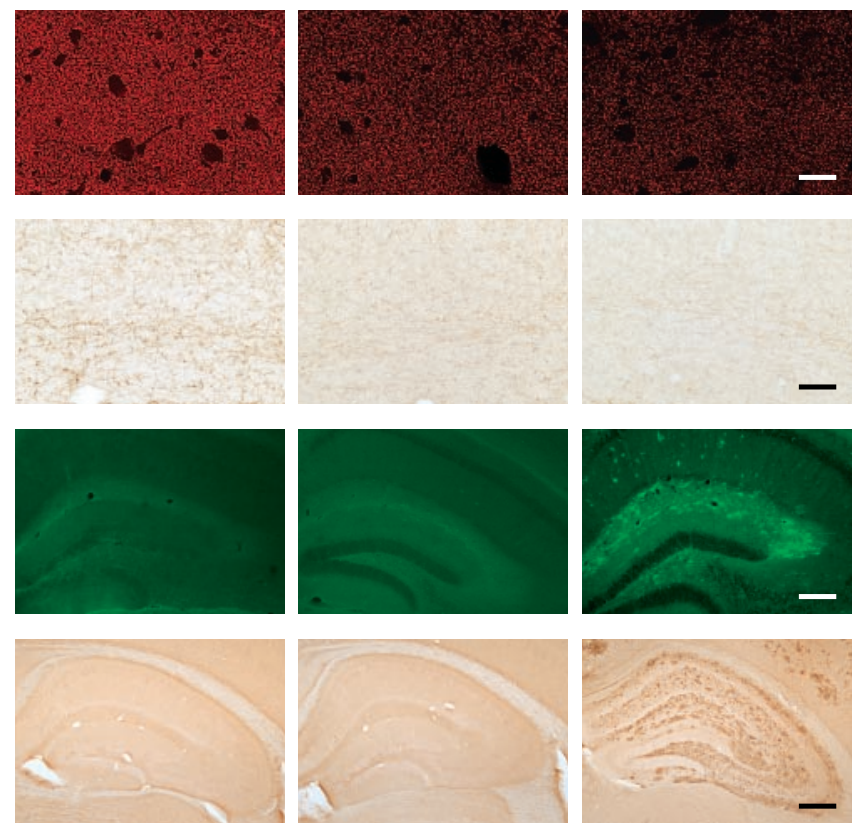

5-7 m

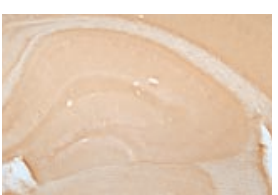

12-15 m
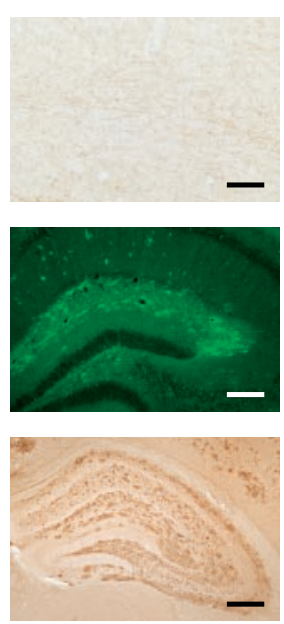

19-24 m

Figure 4. Age-dependent progression of neuropathological alterations in hAPP/apoE3 and hAPP/apoE4 mice. SYN-IR presynaptic terminals (stratum lacunosum) and ChAT-IR fibers (strata lacunosum and radiatum) of defined signal intensity were measured in the hippocampus. Age-dependent decreases in SYN-IR presynaptic terminals developed later in hAPP/apoE3 mice than in hAPP/apoE4 mice. Thio-S-positive plaques and A $\beta$-IR deposits in the hippocampus were detected only in the oldest age group, with more deposits found in hAPP/apoE4 mice than in hAPP/apoE3 mice. Note that 12- to 15-month-old hAPP/apoE4 mice had decreased levels of SYN-IR presynaptic terminals and ChAT-IR fibers but no amyloid deposits, and that 19to 24-month-old hAPP/apoE4 mice had a larger amyloid burden than hAPP/apoE3 mice (Fig. 5), although at this age both groups had comparable decreases in SYN-IR presynaptic terminals and ChAT-IR fibers (Figs. 2, 3). Scale bars: top row, $30 \mu \mathrm{m}$; second row, $65 \mu \mathrm{m}$; third row, $250 \mu \mathrm{m}$; fourth row, $400 \mu \mathrm{m}$.

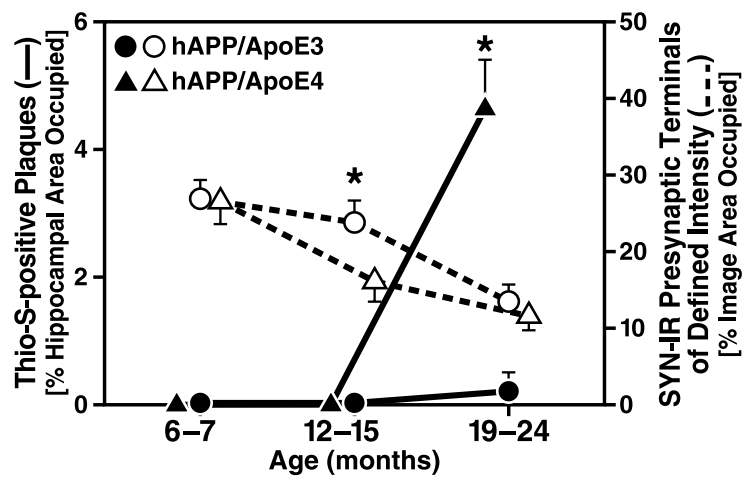

Figure 5. Age-dependent formation of thio-S-positive plaques in the hippocampus of hAPP/apoE mice. Brain sections were stained with thio-S and imaged by confocal microscopy (FITC filter setting). The hippocampal area occupied by thio-S-positive plaques was determined ( $y$-axis on left, solid symbols and lines). Thio-S-positive amyloid plaques were detected only in the 19-24 month age group. hAPP/apoE4 mice had a significantly higher plaque load than hAPP/apoE3 mice. Results represent means \pm SEM; $n=4-7$ mice per genotype and age range; ${ }^{*} p<0.05$ by Mann-Whitney $U$ test. Synaptophysin data (stratum lacunosum) from Figure 2 were superimposed ( $y$-axis on right, open symbols and dashed lines) to highlight that the differential effects of apoE isoforms on plaques and SYN-IR presynaptic terminals occur at different ages.

\section{DISCUSSION}

The current study demonstrates that brain aging in the context of high levels of nondeposited human $\mathrm{A} \beta$ is associated with a progressive loss of SYN-IR presynaptic terminals, ChAT activity, and ChAT-IR fibers. The pace of the synaptic but not of the cholinergic decline was critically influenced by which isoform of human apoE was expressed in the brain. ApoE3 delayed the synaptic decline until old age, whereas apoE4 had no significant protective effects on synapses at any of the ages analyzed. Because synaptic deficits correlate well with the development of cognitive deficits in AD (DeKosky and Scheff, 1990; Terry et al., 1991; Langlais et al., 1993; Samuel et al., 1997; Sze et al., 1997; Brown et al., 1998), the differential effects of apoE3 and apoE4 identified here might relate closely to the effects of these isoforms on $\mathrm{AD}$ risk $(\mathrm{E} 4>\mathrm{E} 3)$ and age of onset $(\mathrm{E} 4<\mathrm{E} 3)$ (Corder et al., 1993; Farrer et al., 1997).

Studies of AD brains have identified a higher plaque burden in people with apoE4 than in people with apoE3 (Berr et al., 1994; Heinonen et al., 1995; Hyman et al., 1995; Ishii et al., 1997; Johnson et al., 1998; McNamara et al., 1998), and these observations have been confirmed in transgenic models expressing these human apoE isoforms in astrocytes (Holtzman et al., 2000a,b) or neurons (this study). These associations have widely been interpreted as evidence that apoE4 increases AD risk through its effect on amyloid deposition (Holtzman et al., 2000a,b; Selkoe, 2001). However, there are several reasons to consider alternative possibilities. 
ApoE4 accelerates AD onset and worsens age-related neuronal decline during the early stages of aging but appears to have relatively little impact on the severity and progression of neuronal deficits in old age and during later stages of AD (Farrer et al., 1997; Bookheimer et al., 2000; Greenwood et al., 2000; Small et al., 2000; Yaffe et al., 2000; Caselli et al., 2001; Chapman et al., 2001; Reiman et al., 2001). In contrast, the effect of apoE4 on amyloid deposition is most prominent in advanced age, both in humans (Berr et al., 1994; Heinonen et al., 1995; Hyman et al., 1995; Ishii et al., 1997; Johnson et al., 1998; McNamara et al., 1998) and in transgenic mice (Holtzman et al., 2000a,b) (this study). ApoE4 increases the plaque burden not only in people with AD but also in nondemented individuals (Berr et al., 1994), underlining the potential dissociation between its effects on amyloid deposition and AD risk/onset. ApoE3 and apoE4 have differential effects on $\mathrm{A} \beta$-dependent memory deficits in hAPP/apoE transgenic mice well before these mice develop amyloid deposits (Raber et al., 2000). Studies in human AD cases and in hAPP transgenic mice have demonstrated that AD-related synaptic and functional neuronal deficits correlate better with levels of nondeposited $\mathrm{A} \beta$ than with plaque load (Holcomb et al., 1999; Hsia et al., 1999; Lue et al., 1999; McLean et al., 1999; Mucke et al., 2000; Raber et al., 2000). In addition, several recent studies of people with one or two $A P O E \in 4$ alleles but without overt AD revealed decreased brain activity, decreased visual attention, and subtle memory impairments in $\epsilon 4$ carriers compared with people with other APOE alleles (Caselli et al., 1999; Bookheimer et al., 2000; Greenwood et al., 2000; Small et al., 2000; Reiman et al., 2001). These findings lend support to the notion that the critical effects of apoE isoforms on AD risk precede the clinical manifestation of AD by many years and, hence, are most likely independent of the prominent plaque formation that occurs during the later stages of the illness.

In the current study, we also detected a higher plaque load in old hAPP/apoE4 mice than in old hAPP/apoE3 mice. However, several findings suggest that this difference does not account for the differential effects of apoE isoforms on age- and $\mathrm{A} \beta$ dependent synaptic and cholinergic decline. First, loss of SYN-IR presynaptic terminals and ChAT-IR fibers in hAPP/apoE4 mice clearly preceded plaque formation. Second, old hAPP/apoE3 and hAPP/apoE4 mice had comparable synaptic and cholinergic deficits but markedly different plaque loads. Third, the agedependent loss of SYN-IR presynaptic terminals and ChAT-IR fibers also affected the neocortex, which was mostly devoid of plaques and $\mathrm{A} \beta$ deposits. Thus, it is likely that a plaqueindependent mechanism accounts for the differential neuroprotective effects observed in our study.

At 12-15 months of age, neocortical levels of SYN-IR presynaptic terminals were significantly lower in hAPP/apoE4 mice than in hAPP/apoE3 mice, although these groups had similar levels of human $\mathrm{A} \beta 1-\mathrm{x}, \mathrm{A} \beta 1-42$, and apoE in the neocortex. Thus, the difference in synaptic integrity in hAPP/apoE3 and hAPP/apoE4 mice was not caused by differences in the abundance of these transgene products. Neuroprotective activities of apoE3 that might allow it to delay age- and $\mathrm{A} \beta$-dependent synaptic deficits include promotion of neurite extension (Nathan et al., 1994; Holtzman and Fagan, 1998) and synapse formation (Mauch et al., 2001), stabilization of microtubules (Strittmatter et al., 1994; Nathan et al., 1995) and endosomal-lysosomal membranes (Ji et al., 2002), and protection against oxidative stress (Miyata and Smith, 1996). Additional studies are needed to determine which of these mechanisms is most important in relation to age- and A $\beta$-dependent neuronal deficits in vivo.

Like the neuronal deficits identified in the current study, behavioral deficits in hAPP/apoE4 mice were seen in both males and females (Raber et al., 2000). In contrast, behavioral deficits in singly transgenic mice expressing apoE4 in the absence of hAPP/A $\beta$ were seen only in females (Raber et al., 1998, 2000). Recent findings suggest that endogenous androgens protect singly transgenic male mice against apoE4-dependent behavioral deficits, and that this protection is relative rather than absolute (Raber et al., 2002).

Although apoE4 failed to prevent the age-dependent synaptic and cholinergic decline that occurs in murine apoE-deficient mice (with or without $\mathrm{A} \beta$ expression), it did not worsen it. This finding may be consistent with a loss of neuroprotective functions of apoE4 compared with apoE3. However, it could also reflect the gain of an adverse activity that counteracts or interferes with beneficial activities of the holoprotein (Raber et al., 1998, 2000; Tolar et al., 1999; Buttini et al., 2000; Huang et al., 2001). The $112_{\text {Cys } \rightarrow \text { Arg }}$ substitution, which differentiates apoE4 from apoE3, affects many aspects of apoE, including its conformation, stability, and binding to lipids and other molecules (Dong and Weisgraber, 1996; Ji et al., 1998; Huang et al., 2001; Raffaï et al., 2001). Determining whether these or other factors account for the lack of neuroprotective effects of apoE4 and its role in AD is an important objective.

Interestingly, overexpression of human $\mathrm{A} \beta$ failed to further augment the age-related synaptic and cholinergic deficits in mice lacking apoE. This finding may be consistent with the notion that the formation of neurotoxic $\mathrm{A} \beta$ species depends on the association of $\mathrm{A} \beta$ with "pathological molecular chaperones," such as apoE and apoJ (Wisniewski and Frangione, 1992; Oda et al., 1995; Ma et al., 1996; Permanne et al., 1997). In the presence of murine apoE (Hsia et al., 1999; Mucke et al., 2000; Masliah et al., 2001) or human apoE (this study), A $\beta$ clearly did affect the integrity or function of presynaptic terminals and cholinergic neurons. Here, $\mathrm{A} \beta$ interfered with the ability of apoE3 to prevent loss of SYN-IR presynaptic terminals in the oldest group of mice and to prevent loss of ChAT-IR fibers at all ages analyzed.

It is interesting to speculate how these results might relate to findings obtained in epidemiological and clinicopathological studies in humans. As in our mouse models, the differential effects of apoE3 and apoE4 on the development of AD manifestations were apparent primarily during early but not late stages of the aging process (Farrer et al., 1997; Bookheimer et al., 2000; Greenwood et al., 2000; Small et al., 2000; Yaffe et al., 2000; Chapman et al., 2001; Reiman et al., 2001). The therapeutic effect of acetylcholinesterase inhibitors during early stages of AD suggests an early impairment of cholinergic functions (Cummings, 2000; Nakano et al., 2001), and there is evidence that the responsiveness to these compounds is influenced by apoE genotype (Farlow et al., 1998). However, biochemical and neuropathological alterations of the cholinergic system have been detected primarily in later stages of the disease, and their modification by apoE isoforms remains controversial (Poirier et al., 1995; Soininen et al., 1995; Allen et al., 1997; Arendt et al., 1997; Salehi et al., 1998; Gilmor et al., 1999; Bronfman et al., 2000; Corey-Bloom et al., 2000; Tiraboschi et al., 2000; Sjögren et al., 2001). Some of the reported discrepancies probably reflect genuine differences in the brain regions, AD populations, or disease models analyzed, but technical differences may also play a role (see Materials and Methods).

In conclusion, apoE3 and apoE4 have differential effects not 
only on amyloid deposition and plaque-associated neuritic dystrophy but also on AD pathologies that appear to be primarily plaque independent, particularly loss of SYN-IR presynaptic terminals. Differences in the ability of these apoE isoforms to protect the brain against nondeposited toxic $\mathrm{A} \beta$ species could contribute to their effects on AD risk and onset. Drugs that simulate apoE3 activities or convert apoE4 into a molecule with apoE3-like function might delay both plaque-dependent and plaque-independent neuronal deficits in the many $A P O E \in 4$ carriers afflicted with or at risk for AD.

\section{REFERENCES}

Allen SJ, MacGowan SH, Tyler S, Wilcock GK, Robertson AGS, Holden PH, Smith SKF, Dawbarn D (1997) Reduced cholinergic function in normal and Alzheimer's disease brain is associated with apolipoprotein E4 genotype. Neurosci Lett 239:33-36.

Arendt T, Schindler C, Brückner MK, Eschrich K, Bigl V, Zedlick D, Marcova L (1997) Plastic neuronal remodeling is impaired in patients with Alzheimer's disease carrying apolipoprotein $\epsilon 4$ allele. J Neurosci 17:516-529.

Berr C, Hauw J-J, Delaäre P, Duyckaerts C, Amouyel P (1994) Apolipoprotein $\mathrm{E}$ allele 4 is linked to increased deposition of the amyloid $\beta$-peptide $(\mathrm{A}-\beta)$ in cases with or without Alzheimer's disease. Neurosci Lett 178:221-224.

Bierer L, Haroutunian V, Gabriel S, Knott PJ, Carlin LS, Purohit DP, Perl DP, Schmeidler J, Kanof P, Davis KL (1995) Neurochemical correlates of dementia severity in Alzheimer's disease: relative importance of the cholinergic deficits. J Neurochem 64:749-760.

Boncristiano S, Calhoun ME, Kelly PH, Pfeifer M, Bondolfi L, Stalder M, Phinney AL, Abramowski D, Sturchler-Pierrat C, Enz A, Sommer B, Staufenbiel M, Jucker M (2002) Cholinergic changes in the APP23 transgenic mouse model of cerebral amyloidosis. J Neurosci 22:32343243 .

Bookheimer SY, Strojwas MH, Cohen MS, Saunders AM, Pericak-Vance MA, Mazziotta JC, Small GW (2000) Patterns of brain activation in people at risk for Alzheimer's disease. N Engl J Med 343:450-456.

Boyles JK, Pitas RE, Wilson E, Mahley RW, Taylor JM (1985) Apolipoprotein $\mathrm{E}$ associated with astrocytic glia of the central nervous system and with nonmyelinating glia of the peripheral nervous system. J Clin Invest 76:1501-1513.

Bronfman FC, Tesseur I, Hofker MH, Havekens LM, Van Leuven F (2000) No evidence for cholinergic problems in apolipoprotein E knockout and apolipoprotein E4 transgenic mice. Neuroscience 97:411-418.

Brown DF, Risser RC, Bigio EH, Tripp P, Stiegler A, Welch E, Eagan KP, Hladik CL, White CLI (1998) Neocortical synapse density and Braak stage in the Lewy body variant of Alzheimer disease: a comparison with classic Alzheimer disease and normal aging. J Neuropathol Exp Neurol 57:955-960.

Buttini M, Orth M, Bellosta S, Akeefe H, Pitas RE, Wyss-Coray T, Mucke L, Mahley RW (1999) Expression of human apolipoprotein E3 or E4 in the brains of Apoe -/- mice: isoform-specific effects on neurodegeneration. J Neurosci 19:4867-4880.

Buttini M, Akeefe H, Lin C, Mahley RW, Pitas RE, Wyss-Coray T, Mucke L (2000) Dominant negative effects of apolipoprotein E4 revealed in transgenic models of neurodegenerative disease. Neuroscience 97:207-210.

Calhoun ME, Wiederhold KH, Abramowski D, Phinney AL, Probst A, Sturchler-Pierrat C, Staufenbiel M, Sommer B, Jucker M (1998) Neuron loss in APP transgenic mice. Nature 395:755-756.

Caselli RJ, Graff-Radford NR, Reiman M, Weaver A, Osborne D, Lucas J, Uecker A, Thibodeau SN (1999) Preclinical memory decline in cognitively normal apolipoprotein E- $\epsilon 4$ homozygotes. Neurology 53:201-207.

Caselli RJ, Osborne D, Reiman EM, Hentz JG, Barbieri CJ, Saunders AM, Hardy J, Graff-Radford NR, Hall GR, Alexander GE (2001) Preclinical cognitive decline in late middle-aged asymptomatic apolipoprotein E- $\epsilon 4 / 4$ homozygotes: a replication study. J Neurol Sci 189:93-98.

Chapman J, Korczyn AD, Karussis DM, Michaelson DM (2001) The effects of $A P O E$ genotype on age at onset and progression of neurodegenerative diseases. Neurology 57:1482-1485.

Corder EH, Saunders AM, Strittmatter WJ, Schmechel DE, Gaskell PC, Small GW, Roses AD, Haines JL, Pericak-Vance MA (1993) Gene dose of apolipoprotein E type 4 allele and the risk of Alzheimer's disease in late onset families. Science 261:921-923.

Corey-Bloom J, Tiraboschi P, Hansen LA, Alford M, Schoos B, Sabbagh MN, Masliah E, Thal LJ (2000) E4 allele dosage does not predict cholinergic activity or synapse loss in Alzheimer's disease. Neurology 54:403-406.
Cummings JL (2000) Cholinesterase inhibitors: a new class of psychotropic compounds. Am J Psychiatry 157:4-15.

Davies P (1979) Neurotransmitter-related enzymes in senile dementia of the Alzheimer type. Brain Res 171:319-327.

Davis JN, Chisholm JC (1997) The "amyloid cascade hypothesis" of AD: decoy or real McCoy? Trends Neurosci 20:558-559.

DeKosky ST, Scheff SW (1990) Synapse loss in frontal cortex biopsies in Alzheimer's disease: correlation with cognitive severity. Ann Neurol 27:457-464.

Dekroon RM, Armati PJ (2001) Synthesis and processing of apolipoprotein $\mathrm{E}$ in human brain cultures. Glia 33:298-305.

Dong LM, Weisgraber KH (1996) Human apolipoprotein E4 domain interaction. Arginine 61 and glutamic acid 255 interact to direct the preference for very low density lipoproteins. J Biol Chem 271:19053-19057.

Farlow MR, Lahiri DK, Poirier J, Davignon J, Schneider L, Hui SL (1998) Treatment outcome of tacrine therapy depends on apolipoprotein genotype and gender of the subjects with Alzheimer's disease. Neurology 50:669-677.

Farrer LA, Cupples LA, Haines JL, Hyman B, Kukull WA, Mayeux R, Myers RH, Pericak-Vance MA, Risch N, van Duijn CM (1997) Effects of age, sex, and ethnicity on the association between apolipoprotein $\mathrm{E}$ genotype and Alzheimer disease. A meta-analysis. JAMA 278:1349-1356.

Games D, Adams D, Alessandrini R, Barbour R, Berthelette P, Blackwell C, Carr T, Clemens J, Donaldson T, Gillespie F, Guido T, Hagopian S, Johnson-Wood K, Khan K, Lee M, Leibowitz P, Lieberburg I, Little S, Masliah E, McConlogue L, et al (1995) Alzheimer-type neuropathology in transgenic mice overexpressing V717F $\beta$-amyloid precursor protein. Nature 373:523-527.

Gearing M, Mori H, Mirra SS (1996) A $\beta$-peptide length and apolipoprotein E genotype in Alzheimer's disease. Ann Neurol 39:395-399.

Geula C, Wu CK, Saroff D, Lorenzo A, Yuan J, Yankner BA (1998) Aging renders the brain vulnerable to amyloid $\beta$-protein neurotoxicity. Nat Med 4:827-831.

Gilmor ML, Erickson JD, Varoqui H, Hersh LB, Bennett DA, Cochran EJ, Mufson EJ, Levey AI (1999) Preservation of nucleus basalis neurons containing choline acetyltransferase and the vesicular acetylcholine transporter in the elderly with mild cognitive impairment and early Alzheimer's disease. J Comp Neurol 411:693-704.

Gordon I, Grauer E, Genis I, Sehayek E, Michaelson DM (1995) Memory deficits and cholinergic impairments in apolipoprotein E-deficient mice. Neurosci Lett 199:1-4.

Greenwood PM, Sunderland T, Friz JL, Parasuraman R (2000) Genetics and visual attention: selective deficits in healthy adult carriers of the $\mathrm{C} \epsilon 4$ allele of the apolipoprotein E gene. Proc Natl Acad Sci USA 97:11661-11666.

Hartley DM, Walsh DM, Ye CP, Diehl T, Vasquez S, Vassilev PM, Teplow DB, Selkoe DJ (1999) Protofibrillar intermediates of amyloid $\beta$-protein induce acute electrophysiological changes and progressive neurotoxicity in cortical neurons. J Neurosci 19:8876-8884.

Heinonen O, Lehtovirta M, Soininen H, Helisalmi S, Mannermaa A, Sorvari H, Kosunen O, Paljärvi L, Ryynänen M, Riekkinen Sr PJ (1995) Alzheimer pathology of patients carrying apolipoprotein E $\epsilon 4$ allele. Neurobiol Aging 16:505-513.

Holcomb LA, Gordon MN, Jantzen P, Hsiao K, Duff K, Morgan D (1999) Behavioral changes in transgenic mice expressing both amyloid precursor protein and presenilin-1 mutations: lack of association with amyloid deposits. Behav Genet 29:177-185.

Holtzman DM, Fagan AM (1998) Potential role of apoE in structural plasticity in the nervous system. Implications for disorders of the central nervous system. Trends Cardiovasc Med 8:250-255.

Holtzman DM, Bales KR, Wu S, Bhat P, Parsadanian M, Fagan AM, Chang LK, Sun Y, Paul SM (1999) Expression of human apolipoprotein $\mathrm{E}$ reduces amyloid- $\beta$ deposition in a mouse model of Alzheimer's disease. J Clin Invest 103:R15-R21.

Holtzman DM, Bales KR, Tenkova T, Fagan AM, Parsadanian M, Sartorius LJ, Mackey B, Olney J, McKeel D, Wozniak D, Paul SM (2000a) Apolipoprotein E isoform-dependent amyloid deposition and neuritic degeneration in a mouse model of Alzheimer's disease. Proc Natl Acad Sci USA 97:2892-2897.

Holtzman DM, Fagan AM, Mackey B, Tenkova T, Sartorius L, Paul SM, Bales K, Ashe KH, Irizarry MC, Hyman BT (2000b) Apolipoprotein $\mathrm{E}$ facilitates neuritic and cerebrovascular plaque formation in an Alzheimer's disease model. Ann Neurol 47:739-747.

Horsburgh K, McCulloch J, Nilsen M, Roses AD, Nicoll JAR (2000) Increased neuronal damage and apoE immunoreactivity in human apolipoprotein E, E4 isoform-specific, transgenic mice after global cerebral ischaemia. Eur J Neurosci 12:4309-4317.

Hsia A, Masliah E, McConlogue L, Yu G, Tatsuno G, Hu K, Kholodenko D, Malenka RC, Nicoll RA, Mucke L (1999) Plaque-independent disruption of neural circuits in Alzheimer's disease mouse models. Proc Natl Acad Sci USA 96:3228-3233.

Huang Y, Schwendner SW, Rall Jr SC, Mahley RW (1996) Hypolipi- 
demic and hyperlipidemic phenotypes in transgenic mice expressing human apolipoprotein E2. J Biol Chem 271:29146-29151.

Huang Y, Liu XQ, Wyss-Coray T, Brecht WJ, Sanan DA, Mahley RW (2001) Apolipoprotein E fragments present in Alzheimer's disease brains induce neurofibrillary tangle-like intracellular inclusions in neurons. Proc Natl Acad Sci USA 98:8838-8843.

Hyman BT, West HL, Rebeck GW, Buldyrev SV, Mantegna RN, Ukleja M, Havlin S, Stanley HE (1995) Quantitative analysis of senile plaques in Alzheimer disease: observation of log-normal size distribution and molecular epidemiology of differences associated with apolipoprotein E genotype and trisomy 21 (Down syndrome). Proc Natl Acad Sci USA 92:3586-3590.

Ishii K, Tamaoka A, Mizusawa H, Shoji S, Ohtake T, Fraser PE, Takahashi H, Tsuji S, Gearing M, Mizutani T, Yamada S, Kato M, St. George-Hyslop PH, Mirra SS, Mori H (1997) A $\beta 1-40$ but not A $\beta 1-42$ levels in cortex correlate with apolipoprotein $E$ $\epsilon 4$ allele dosage in sporadic Alzheimer's disease. Brain Res 748:250-252.

Ji ZS, Pitas RE, Mahley RW (1998) Differential cellular accumulation/ retention of apolipoprotein E mediated by cell surface heparan sulfate proteoglycans. J Biol Chem 273:13452-13460.

Ji ZS, Miranda RD, Newhouse YM, Weisgraber KH, Huang Y, Mahley RW (2002) Apolipoprotein E4 potentiates amyloid $\beta$ peptide-induced lysosomal leakage and apoptosis in neuronal cells. $\mathrm{J}$ Biol Chem 277:21821-21828.

Johnson JK, McCleary R, Oshita MH, Cotman CW (1998) Initiation and propagation stages of $\beta$-amyloid are associated with distinctive apolipoprotein E, age, and gender profiles. Brain Res 798:18-24.

Johnson-Wood K, Lee M, Motter R, Hu K, Gordon G, Barbour R, Khan K, Gordon M, Tan H, Games D, Lieberburg I, Schenk D, Seubert P, McConlogue L (1997) Amyloid precursor protein processing and $\mathrm{A} \beta_{42}$ deposition in a transgenic mouse model of Alzheimer disease. Proc Natl Acad Sci USA 94:1550-1555.

Klein WL, Krafft GA, Finch CE (2001) Targeting small A $\beta$ oligomers: the solution to an Alzheimer's disease conundrum. Trends Neurosci 24:219-224.

Knowles RB, Wyart C, Buldyrev SV, Cruz L, Urbanc B, Hasselmo ME, Stanley HE, Hyman BT (1999) Plaque-induced neurite abnormalities: implications for disruption of neural networks in Alzheimer's disease. Proc Natl Acad Sci USA 96:5274-5279.

Lambert MP, Barlow AK, Chromy BA, Edwards C, Freed R, Liosatos M, Morgan TE, Rozovsky I, Trommer B, Viola KL, Wals P, Zhang C, Finch CE, Krafft GA, Klein WL (1998) Diffusible, nonfibrillar ligands derived from $\mathrm{A} \beta_{1-42}$ are potent central nervous system neurotoxins. Proc Natl Acad Sci USA 95:6448-6453.

Langlais PJ, Thal L, Hansen L, Galasko D, Alford M, Masliah E (1993) Neurotransmitters in basal ganglia and cortex of Alzheimer's disease with and without Lewy bodies. Neurology 43:1927-1934.

Lue L-F, Kuo Y-M, Roher AE, Brachova L, Shen Y, Sue L, Beach T, Kurth JH, Rydel RE, Rogers J (1999) Soluble amyloid $\beta$ peptide concentration as a predictor of synaptic change in Alzheimer's disease. Am J Pathol 155:853-862.

Ma J, Brewer Jr HB, Potter H (1996) Alzheimer A $\beta$ neurotoxicity: promotion by antichymotrypsin, ApoE4: inhibition by A $\beta$-related peptides. Neurobiol Aging 17:773-780.

Mahley R, Huang Y (1999) Apolipoprotein E: from atherosclerosis to Alzheimer's disease and beyond. Curr Opin Lipidol 10:207-217.

Masliah E, Mallory M, Alford M, Ge N, Mucke L (1995a) Abnormal synaptic regeneration in hAPP695 transgenic and apoE knockout mice. In: Research advances in Alzheimer's disease and related disorders (Iqbal K, Mortimer J, Winblad B, Wisniewski H, eds), pp 405-414. New York: Wiley.

Masliah E, Mallory M, Ge N, Alford M, Veinbergs I, Roses AD (1995b) Neurodegeneration in the central nervous system of apoE-deficient mice. Exp Neurol 136:107-122.

Masliah E, Sisk A, Mallory M, Mucke L, Schenk D, Games D (1996) Comparison of neurodegenerative pathology in transgenic mice overexpressing V717F $\beta$-amyloid precursor protein and Alzheimer's disease. J Neurosci 16:5795-5811.

Masliah E, Rockenstein E, Veinbergs I, Sagara Y, Mallory M, Hashimoto M, Mucke L (2001) $\beta$-Amyloid peptides enhance $\alpha$-synuclein accumulation and neuronal deficits in a transgenic mouse model linking Alzheimer's disease and Parkinson's disease. Proc Natl Acad Sci USA 98:12245-12250.

Mauch DH, Nägler K, Schumacher S, Göritz C, Müller E-C, Otto A, Pfrieger FW (2001) CNS synaptogenesis promoted by glia-derived cholesterol. Science 294:1354-1357.

McLean CA, Cherny RA, Fraser FW, Fuller SJ, Smith MJ, Beyreuther K, Bush AI, Masters CL (1999) Soluble pool of A $\beta$ amyloid as a determinant of severity of neurodegeneration in Alzheimer's disease. Ann Neurol 46:860-866.

McNamara MJ, Gomez-Isla T, Hyman BT (1998) Apolipoprotein E genotype and deposits of $\mathrm{A} \beta 40$ and $\mathrm{A} \beta 42$ in Alzheimer disease. Arch Neurol 55:1001-1004.

Miyata M, Smith JD (1996) Apolipoprotein E allele-specific antioxidant activity and effects on cytotoxicity by oxidative insults and $\beta$-amyloid peptides. Nat Genet 14:55-61.

Mucke L, Masliah E, Yu G-O, Mallory M, Rockenstein EM, Tatsuno G, $\mathrm{Hu}$ K, Kholodenko D, Johnson-Wood K, McConlogue L (2000) High-level neuronal expression of $\mathrm{A} \beta_{1-42}$ in wild-type human amyloid protein precursor transgenic mice: synaptotoxicity without plaque formation. J Neurosci 20:4050-4058.

Nakano S, Asada T, Matsuda H, Uno M, Takasaki M (2001) Donepezil hydrochloride preserves regional cerebral blood flow in patients with Alzheimer's disease. J Nucl Med 42:1441-1445.

Nalbantoglu J, Tirado-Santiago G, Lahasaïni A, Poirier J, Goncalves O, Verge G, Momoli F, Welner SA, Massicotte G, Julien JP, Shapiro ML (1997) Impaired learning and LTP in mice expressing the carboxy terminus of the Alzheimer amyloid precursor protein. Nature 387:500-505.

Näslund J, Haroutunian V, Mohs R, Davis KL, Davies P, Greengard P, Buxbaum JD (2000) Correlation between elevated levels of amyloid $\beta$-peptide in the brain and cognitive decline. JAMA 283:1571-1577.

Nathan BP, Bellosta S, Sanan DA, Weisgraber KH, Mahley RW, Pitas RE (1994) Differential effects of apolipoproteins E3 and E4 on neuronal growth in vitro. Science 264:850-852.

Nathan BP, Chang K-C, Bellosta S, Brisch E, Ge N, Mahley RW, Pitas RE (1995) The inhibitory effect of apolipoprotein E4 on neurite outgrowth is associated with microtubule depolymerization. J Biol Chem 270:19791-19799.

Neary D, Snowden JS, Mann DMA, Bowen DM, Sims NR, Northen B, Yates PO, Davison AN (1986) Alzheimer's disease: a correlative study. J Neurol Neurosurg Psychiatry 49:229-237.

Oda T, Wals P, Osterburg HH, Johnson SA, Pasinetti GM, Morgan TE, Rozovsky I, Stine WB, Snyder SW, Holzman TF, Krafft GA, Finch CE (1995) Clusterin (apoJ) alters the aggregation of amyloid $\beta$-peptide $\left(\mathrm{A} \beta_{1-42}\right)$ and forms slowly sedimenting $\mathrm{A} \beta$ complexes that cause oxidative stress. Exp Neurol 136:22-31.

Permanne B, Perez C, Soto C, Frangione B, Wisniewski T (1997) Detection of apolipoprotein $\mathrm{E} /$ dimeric soluble amyloid $\beta$ complexes in Alzheimer's disease brain supernatants. Biochem Biophys Res Commun 240:715-720.

Perry EK, Tomlinson BE, Blessed G, Bergmann K, Gibson PH, Perry RH (1978) Correlation of cholinergic abnormalities with senile plaques and mental test scores in senile dementia. Br Med J 2:1457-1459.

Pike CJ, Burdick D, Walencewicz AJ, Glabe CG, Cotman CW (1993) Neurodegeneration induced by $\beta$-amyloid peptides in vitro: the role of peptide assembly state. J Neurosci 13:1676-1687.

Poirier J, Delisle MC, Quirion R, Aubert I, Farlow M, Lahiri D, Hui S, Bertrand P, Nalbantoglu J, Gilfix BM, Gauthier S (1995) Apolipoprotein E4 allele as a predictor of cholinergic deficits and treatment outcome in Alzheimer disease. Proc Natl Acad Sci USA 92:12260-12264.

Price DL, Sisodia SS, Borchelt DR (1998) Genetic neurodegenerative diseases: the human illness and transgenic models. Science 282:10791083.

Raber J, Wong D, Buttini M, Orth M, Bellosta S, Pitas RE, Mahley RW, Mucke L (1998) Isoform-specific effects of human apolipoprotein $\mathrm{E}$ on brain function revealed in $A p o E$ knockout mice: increased susceptibility of females. Proc Natl Acad Sci USA 95:10914-10919.

Raber J, Wong D, Yu G-Q, Buttini M, Mahley RW, Pitas RE, Mucke L (2000) Alzheimer's disease: apolipoprotein E and cognitive performance. Nature 404:352-354.

Raber J, LeFevour A, Buttini M, Mucke L (2002) Androgens protect against apolipoprotein E4-induced cognitive deficits. J Neurosci 22:5204-5209.

Raffaï RL, Dong LM, Farese Jr RV, Weisgraber KH (2001) Introduction of human apolipoprotein E4 "domain interaction" into mouse apolipoprotein E. Proc Natl Acad Sci USA 98:11587-11591.

Rebeck GW, Reiter JS, Strickland DK, Hyman BT (1993) Apolipoprotein $\mathrm{E}$ in sporadic Alzheimer's disease: allelic variation and receptor interactions. Neuron 11:575-580.

Reiman EM, Caselli RJ, Chen KW, Alexander GE, Bandy D, Frost J (2001) Declining brain activity in cognitively normal apolipoprotein $\mathrm{E}$ $\mathrm{C} \epsilon 4$ heterozygotes: a foundation for using positron emission tomography to efficiently test treatments to prevent Alzheimer's disease. Proc Natl Acad Sci USA 98:3334-3339.

Sabo T, Lomnitski L, Nyska A, Beni S, Maronpot RR, Shohami E, Roses AD, Michaelson DM (2000) Susceptibility of transgenic mice expressing human apolipoprotein $\mathrm{E}$ to closed head injury: the allele E3 is neuroprotective whereas E4 increases fatalities. Neuroscience $101: 879-884$

Salehi A, Dubelaar EJG, Mulder M, Swaab DF (1998) Aggravated decrease in the activity of nucleus basalis neurons in Alzheimer's disease is apolipoprotein E-type dependent. Proc Natl Acad Sci USA 95:11445-11449.

Samuel W, Alford M, Hofstetter CR, Hansen L (1997) Dementia with Lewy bodies versus pure Alzheimer disease: differences in cognition, neuropathology, cholinergic dysfunction, and synapse density. J Neuropathol Exp Neurol 56:499-508.

Schmechel DE, Saunders AM, Strittmatter WJ, Crain BJ, Hulette CM, 
Joo SH, Pericak-Vance MA, Goldgaber D, Roses AD (1993) Increased amyloid $\beta$-peptide deposition in cerebral cortex as a consequence of apolipoprotein $\mathrm{E}$ genotype in late-onset Alzheimer disease. Proc Natl Acad Sci USA 90:9649-9653.

Schmidt ML, Robinson KA, Lee VM-Y, Trojanowski JQ (1995) Chemical and immunological heterogeneity of fibrillar amyloid in plaques of Alzheimer's disease and Down's syndrome brains revealed by confocal microscopy. Am J Pathol 147:503-515.

Selkoe DJ (2001) Alzheimer's disease: genes, proteins, and therapy. Physiol Rev 81:741-766.

Sheng HX, Laskowitz DT, Bennett E, Schmechel DE, Bart RD, Saunders AM, Pearlstein RD, Roses AD, Warner DS (1998) Apolipoprotein E isoform-specific differences in outcome from focal ischemia in transgenic mice. J Cereb Blood Flow Metab 18:361-366.

Sims NR, Bowen DM, Allen SJ, Smith CCT, Neary D, Thomas DJ, Davison AN (1983) Presynaptic cholinergic dysfunction in patients with dementia. J Neurochem 40:503-509.

Sjögren M, Hesse C, Basun H, Köl G, Thostrup H, Kilander L, Marcusson J, Edman $\AA$, Wallin A, Karlsson I, Troell M, Wachtmaister G, Ekdahl A, Olofsson H, Sandström A, Andreasen N, Minthon L, Blennow K (2001) Tacrine and rate of progression in Alzheimer's disease. Relation to ApoE allele genotype. J Neural Transm 108:451-458.

Small GW, Ercoli LM, Silverman DHS, Huang SC, Komo S, Bookheimer SY, Lavretsky H, Miller K, Siddarth P, Rasgon NL, Mazziotta JC, Saxena S, Wu HM, Mega MS, Cummings JL, Saunders AM, PericakVance MA, Roses AD, Barrio JR, Phelps ME (2000) Cerebral metabolic and cognitive decline in persons at genetic risk for Alzheimer's disease. Proc Natl Acad Sci USA 97:6037-6042.

Soininen H, Kosunen O, Helisalmi S, Mannermaa A, PaljÑrvi L, Talasniemi S, RyynNnen M, Riekkinen Sr P (1995) A severe loss of choline acetyltransferase in the frontal cortex of Alzheimer patients carrying apolipoprotein $\epsilon 4$ allele. Neurosci Lett 187:79-82.

Stone DJ, Rozovsky I, Morgan TE, Anderson CP, Hajian H, Finch CE (1997) Astrocytes and microglia respond to estrogen with increased apoE mRNA in vivo and in vitro. Exp Neurol 143:313-318.

Strittmatter WJ, Weisgraber KH, Goedert M, Saunders AM, Huang D, Corder EH, Dong L-M, Jakes R, Alberts MJ, Gilbert JR, Han S-H, Hulette C, Einstein G, Schmechel DE, Pericak-Vance MA, Roses AD (1994) Microtubule instability and paired helical filament formation in the Alzheimer disease brain are related to apolipoprotein E genotype. Exp Neurol 125:163-171.

Sze CI, Troncoso JC, Kawas C, Mouton P, Price DL, Martin LJ (1997)
Loss of the presynaptic vesicle protein synaptophysin in hippocampus correlates with cognitive decline in Alzheimer disease. J Neuropathol Exp Neurol 56:933-944.

Terry RD (1996) The pathogenesis of Alzheimer disease: an alternative to the amyloid hypothesis. J Neuropathol Exp Neurol 55:1023-1025.

Terry RD, Masliah E, Salmon DP, Butters N, DeTeresa R, Hill R, Hansen LA, Katzman R (1991) Physical basis of cognitive alterations in Alzheimer's disease: synapse loss is the major correlate of cognitive impairment. Ann Neurol 30:572-580.

Terry RD, Masliah E, Hansen LA (1999) The neuropathology of Alzheimer disease and the structural basis of its cognitive alterations. In: Alzheimer disease, Ed 2 (Terry RD, Katzman R, Bick KL, Sisodia SS, eds), pp 187-206. Philadelphia: Lippincott Williams and Wilkins.

Tiraboschi P, Hansen LA, Alford M, Masliah E, Thal LJ, Corey-Bloom J (2000) The decline in synapses and cholinergic activity is asynchronous in Alzheimer's disease. Neurology 55:1278-1283.

Tolar M, Keller JN, Chan S, Mattson MP, Marques MA, Crutcher KA (1999) Truncated apolipoprotein E (apoE) causes increased intracellular calcium and may mediate apoE neurotoxicity. J Neurosci 19:7100-7110.

Wilcock GK, Esiri MM, Bowen DM, Smith CCT (1982) Alzheimer's disease: correlation of cortical acetyltransferase activity with the severity of dementia and histological abnormalities. J Neurol Sci 57:407-417.

Wisniewski T, Frangione B (1992) Apolipoprotein E: a pathological chaperone protein in patients with cerebral and systemic amyloid. Neurosci Lett 135:235-238.

Xu PT, Gilbert JR, Qui H, Ervin J, Rothrock-Christian TR, Hulette C, Schmechel DE (1999) Specific regional transcription of apolipoprotein $\mathrm{E}$ in human brain neurons. Am J Pathol 154:1-11.

Xu Q, Li Y, Cyras C, Sanan DA, Cordell B (2000) Isolation and characterization of apolipoproteins from murine microglia. Identification of a low density lipoprotein-like apolipoprotein J-rich but E-poor spherical particle. J Biol Chem 275:31770-31777.

Yaffe K, Haan M, Byers A, Tangen C, Kuller L (2000) Estrogen use, APOE, and cognitive decline. Evidence of gene-environment interaction. Neurology 54:1949-1953.

Yankner BA (1996) Mechanisms of neuronal degeneration in Alzheimer's disease. Neuron 16:921-932.

Yeo TT, Chua-Couzens J, Butcher LL, Bredesen DE, Cooper JD, Valletta JS, Mobley WC, Longo FM (1997) Absence of p75 NTR causes increased basal forebrain cholinergic neuron size, choline acetyltransferase activity, and target innervation. J Neurosci 17:7594-7605. 